\title{
PEMBINAAN PERKEMBANGAN KEBERAGAMAAN ANAK USIA DINI
}

\author{
Oleh: Asnelly Ilyas*
}

\begin{abstract}
Among potentials that children have as they were born, religious potential is one that needs to be developed in line with other potentials by means of education. Pre-school aged children refer to those who are between 0 and 6 years old. They are in their ultimate growing and developing period in intelligence, emotion, social, and language. Specifically, characteristics of religious awareness among children is reflected in the form of unreflective, egocentrical, antropomorphical, vebal, ritual and imitative. Introducing and familiarizing religious among children can be done by making use of their initial growth and developing through good model, stories, field trip to behold the great and glory of Allah, to get used to worship, good moral, help each other, and so on. It is believed that introducing religion in early ages will provide children with guidance and foundation in their life.
\end{abstract}

Kata Kunci: anak usia dini, pertumbuhan, perkembangan, keberagamaan

\section{PENDAHULUAN}

A 1-Gazali berkata "anak itu amanah bagi kedua orang tuanya. Hatinya bersih bagaikan mutiara yang indah, bersahaja, bersih dari setiap lukisan dan gambar. Ia akan menerima bagi setiap yang dilukiskan, cenderung kearah apa saja yang diarahkan kepadanya. Jika ia dibiasakan dan di ajar yang baik, ia dapat tumbuh dengan baik, beruntung di dunia dan diakhirat. Kedua orang tuanya, semua gurunya, pengajarnya dan yang mendidiknya sama-sama dapat menerima pahala. Dan jika ia dibiasakan melakukan keburukan dan dibiarkan sebagaimana membiarkan binatang, ia celaka dan rusak, adalah dosanya menimpa pangasuh dan walinya (Abu Ahmadi, 1990:5).

Agar mutiara yang indah dan bersih itu terjaga dari lukisan dan gambar yang kotor, maka salah satu upaya yang dilakukan adalah dengan memberikan pendidikan sejak anak usia dini, pendidikan dalam arti usaha, upaya serta kegiatan yang dilakukan dalam rangka mempersiapkan anak untuk tumbuh dan berkembang dengan semua potensi agar ia dapat hidup dan berpenghidupan sempurna serta ia dapat menjadi anggota masyarakat yang berguna bagi dirinya dan umat.

Akhir-akhir ini diketahui melalui siaran televisi, majalah, koran dan media lainnya memberitakan tentang kenakalan-kenakalan dan kriminal yang dilakukan oleh remaja-remaja termasuk anakanak seperti tawuran antar sekolah, norkoba, dan menganiaya orang tua karena keinginannya tidak dapat dikabulkan oleh orang tua.

Tulisan ini akan mengungkapkan tugas dan tanggung jawab pendidik dalam mananamkan nilai-nilai agama Islam pada anak usia dini sebagai pondasi dalam menjalani kehidupan.

* Penulis adalah Lektor Kepala dalam Mata Kuliah Evaluasi Pendidikan STAIN Batusangkar 


\section{PENGERTIAN ANAK USIA DINI}

Sebelum membicarakan lebih lanjut tentang penanaman nilai-nilai Agama Islam pada anak usia dini, terlebih dahulu dibicarakan tentang hal-hal yang terkait dengan anak usia dini tersebut.

Anak usia dini adalah sekelompok anak yang berada dalam proses pertumbuhan dan perkembangan unik. Anak memiliki pola pertumbuhan dan perkembangan (koordinasi motorik halus dan kasar) daya pikir, daya cipta, bahasa dan komonikasi, yang tercakup dalam kecerdasan Intelegence Question (IQ), Emosional Question (EQ),Spritual Question (SQ), atau kecerdasan agama atau (Relegius Question sesuai dengan tingkat pertumbuhan dan perkembangan anak.

Pertumbuhan dan perkembangan anak usia dini perlu diarahkan pada peletakan dasar-dasar yang tepat bagi pertumbuhan dan perkembangan manusia seutuhnya. Hal ini meliputi pertumbuhan fisik dan perkembangan psikis, daya pikir, daya cipta, emosonal, bahasa komonikasi seimbang sebagai dasar pembentukan pribadi yang utuh, agar anak dapat tumbuh dan berkembang secara optimal.

Anak usia dini adalah kelompok manusia yang berusia 0-6 tahun, demikian menurut undang-undang RI No.20 tahun 2003 tentang Sitem Pendidikan nasional. Menurut pakar pendidikan anak, anak usia dini adalah kelompok manusia yang berumur 0-6 tahun, anak yang berada dalam proses pertumbuhan dan perkembangan yang bersifat unik dalam arti memiliki pola pertumbuhan dan perkembangan (kordinasi motorik halus dan kasar), intelegensi (daya pikir, cipta, kecerdasan emosional, dan kecerdasan spritual), sosial emosional (sikap dan prilaku serta agama), bahasa dan komonikasi yang khusus sesuai dengan tingkat pertumbuhan dan perkembangan anak (Mansur, 2005:88).
Berdasarkan keunikan dalam pertumbuhan dan perkembangannya anak usia dini terbagi dalam tiga tingkat; 1). masa bayi lahir sampai 12 bulan, 2.) masa toddler (balita) usia 1-3 tahun 3). masa pra sekolah usia 4-6 tahun. 4) masa kelas awal SD 6-8 tahun. Pada masa anak usia dini sangat perlu diarahkan pertumbuhan dan perkembangan kepada peletakan dasar-dasar yang tepat menuju manusia seutuhnya. Pertumbuhan fisik dan perkembangan psikis seperti daya pikir, daya cipta, karsa, rasa dan dimensi kemanusian yang seimbang dalam pembentukan pribadi yang utuh.

\section{PERKEMBANGAN AGAMA PADA ANAK USIA DINI}

Sebelum membicarakan perkembangan agama pada anak usia dini ada baiknya dipahami terlebih dahulu timbulnya jiwa keagamaan pada anak. Pertama Karena ketergantungan (sense of depende) maksudnya adalah manusia dilahirkan ke dunia ini memiliki empat kebutuhan yakni keinginan untuk perlindungan (security), keinginan akan pengalaman baru (new experience), keinginan untuk mendapatkan tanggapan (response) dan keinginan untuk dikenal (recognition). Berdasarkan kenyataan dan kerjasama dari empat keinginan itu, maka bayi sejak dilahirkan hidup dalam ketergantungan. Melalui pengalamanpengalaman yang diterimanya dari lingkungan itu kemudiaan terbentuklah rasa keagamaan pada diri anak. Kedua Instink Keagamaan, Bayi yang sudah dilahirkan sudah membawa fitrah agama sebagaimana yang dijelaskan dalam firman Allah dalam surat Ar-Rum ayat 30 yang berbunyi:

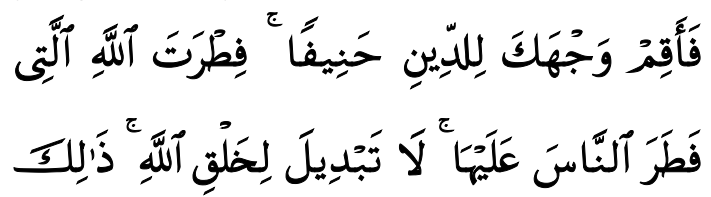




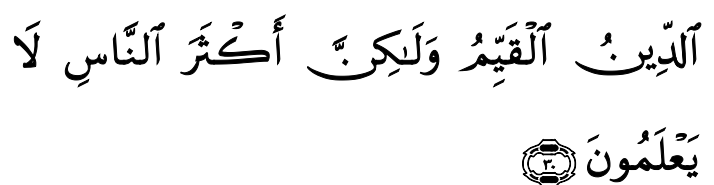

"Maka hadapkanlah wajahmu dengan lurus kepada agama Allah; (tetaplah atas) fitrah Allah yang telah menciptakan manusia menurut fitrah itu. Tidak ada peubahan pada fitrah Allah. (Itulah) agama yang lurus; tetapi kebanyakan manusia tidak mengetahui”.

Dari ayat tersebut di atas dapat dipahami bahwa manusia sebelum lahirnya sudah dibekali dengan fitrah (potensi) beragama tauhid. Fitrah Allah: maksudnya ciptaan Allah. Manusia diciptakan Allah mempunyai naluri beragama yaitu agama tauhid. Kalau ada manusia tidak beragama tauhid, maka hal itu tidaklah wajar. Mereka tidak beragama tauhid itu hanyalah lantaran pengaruh lingkungan,karena itu pendidikan agama dan penanaman nilai-nilai keagamaan seharusnya sudah dimulai ketika anak masih dalam kandungan ibu dengan istilah lain pendidikan pra natal (pendidikan sebelum lahir) melalui sikap dan prilaku keagamaan orang tua secara tidak langsung menanamkan nilai-nilai keagamaan pada anak setelah lahir dengan perkataan-perkataan dan ungkapanungkapan yang baik, serta perbuatanperbuatan yang berhubungan antara manusia dengan Tuhan dan hubungan antar sesama manusia serta lingkungan.

Hanna Djumhana Bastaman dalam (Baharuddin dan Mulyono, 2008:91) berpendapat bahwa fitrah manusia adalah suci dan beriman. Kecenderungan kepada agama adalah merupakan sifat dasar manusia, sadar atau tidak sadar manusia selalu merindukan Tuhan dan seterusnya. Sejak kelahirannya manusia telah diciptakan Allah membawa potensi keberagamaan yang benar, (tauhid), atau dengan kata lain melalui fitrah dalam diri manusia terdapat sejenis bawaan potensi dasar, yang berisi keyakinan terhadap Allah swt, yang disebut religius instinct (naluri keberagamaan).

Ada beberapa tingkat perkembangan agama anak usia dini:

\section{Fase Dongeng (The Fairy Tale Stage)}

Pada fase ini dimulai pada usia 3-6 tahun, anak dalam tingkatan ini mengenal konsep Tuhan lebih banyak dipengaruhi oleh fantasi dan emosi. Anak menghayati konsep ketuhanan sesuai dengan tingkat perkembangan intelektual anak, pada fase ini banyak dipengaruhi kehidupan fantasi sehingga dalam memahami agama pun anak masih menggunakan konsep fantastis yang diliputi oleh dongeng yang kadang-kadang kurang masuk akal (Sugeng Hariyadi, 2003.5-6).

\section{Fase Kenyataan (The Realistic Stage)}

Pada tingkat ini dimulai sejak anak masuk SD hingga sampai keusia adolensense. Pada masa ini ide ketuhanan anak sudah mencerminkan konsep-konsep yang berdasarkan kepada kenyataan (realistis). Konsep ini muncul ketika anak-anak tersebut belajar agama pada lembaga-lembaga keagamaan dan dengan orang dewasa, sehingga ide keagamaan anak didasarkan atas dorongan emosional yang dapat melahirkan konsep Tuhan yang formalis.

\section{Fase Induvidu (The Induvidual Stage).}

Anak pada fase ini memiliki kepekaan emosi yang paling tinggi sejalan dengan perkembangan usia mereka (Sugeng Haryadi, 2003:67) Fase ini diperkenalkan nilai-nilai keagamaan pada anak usia dini dengan alasan anak telah memiliki minat beragama, prilaku anak membentuk suatu pola prilaku, mengasah potensi positif diri sebagai induvidu, makhluk sosial dan hamba Allah, agar minat anak tumbuh subur, harus dilatih dengan cara yang menye- 
nangkan agar anak tidak merasa terpaksa dalam melakukan kegiatan keagamaan.

Cara-cara yang dilakukan orang tua untuk mengasah kecerdasan spiritual anak adalah antara lain dengan memberi contoh tauladan, karena anak pada masa ini suka meniru. Orang tua merupakan lingkungan pertama yang ditemui oleh anak, maka anak cenderung meniru apa yang diperbuat oleh orang tuanya, disinilah peran orang tua untuk memberi contoh yang baik bagi anak-usia dini. Dalam mengajarkan nilai-nilai keagamaan pada anak usia dini diperlukan kesabaran, tidak semua yang kita lakukan berhasil pada saat itu, adakalanya memerlukan waktu yang lama dan berulang demikian Mansur menjelaskan (Mansur, 2007:50).

Menurut Komaruddin Hidayat, hakikat spiritual anak-anak tercermin dalam sikap spontan, imajinasi, dan kreativitas yang tak terbatas, dan semua itu dilakukan dengan terbuka serta ceria (Komaruddin Hidayat, 2003:11). Spiritual adalah dasar bagi tumbuhnya harga diri, nilai-nilai agama, dan moral. Spiritual memberi arah dan arti pada kehidupan anak. Caranya dengan melalui perkataan, tindakan, dan perhatian pada indahnya alam. Anak memperhatikan prilaku alam yang akan mengundang ketakjuban anak terhadap keindahan alam, dimana ada ketakjuban maka disana ada spiritualitas. Selanjutnya Komoruddin Hidayat menjelaskan ada 10 macam cara untuk menumbuh dan mengembangkan kecerdasan spiritualitas anak a) Ajarkan kepada anak bahwa Tuhan selalu memperhatikan kehidupan kita, b) Ajarkan kepada anak-anak bahwa hidup dan kehidupan ini saling berhubungan, c) Jadilah pendengar yang baik bagi anak-anak, d) Ajarkan anak untuk menggunakan kata dan ungkapan yang bagus, indah, dan mendorong imajinasi e) Doronglah anak-anak untuk berimajinasi tentang masa depannya dan tentang kehidup- annya, f) Temukan dan tanyakan keajaiban yang terjadi setiap hari atau minggu, g) Berikan ruang kepada anak untuk berkreasi, menentukan program, dan jadwal kegiatan h) Jadilah cermin positif bagi anak-anak, i) sekali-kali ciptakan suasana yang benar-benar santai j) Lepaskan semua kepanikan dan ketengangan fisik dan psikis, k) Setiap hari adalah istimewa yang wajib dihayati dan disyukuri.

Pada fase ketiga ini, tingkat kepekaan anak paling tinggi sejalan dengan perkembangan usia mereka. Pada tahap ini konsep keagamaan yang induvidual ini terbagi pada tiga golongan: 1) Konsep ketuhanan yang konvensional dan konservatif dengan dipengaruhi oleh sebahagian kecil fantasi. Hal ini disebabkan oleh pengaruh dari luar, 2) Konsep ketuhanan yang lebih murni yang dinyatakan dalam pandangan yang bersifat personal, 3). Konsep ketuhanan yang bersifat humanistik. Agama telah menjadi etos humanis pada diri mereka dalam menghayati ajaran agama. Perubahan ini setiap tingkatan dipengaruhi oleh faktor internal, yakni perkembangan usia dan faktor ekternal berupa pengaruh dari luar.

\section{SIFAT-SIFAT AGAMA ANAK USIA DINI}

Mansur, (2005:53-54) dan Jalaluddin (2007:70-74 )mengungkapkan sifat dan bentuk keagamaan anak usia dini antara lain pertama: tidak mendalam atau Unreflective artinya anak menerima ajaran agama tanpa kritik, kebenaran yang mereka terima tidak begitu mendalam sehingga cukup sekedarnya saja dan mereka sudah merasa puas dengan keterangan yang kadang-kadang kurang masuk akal.

Sifat kedua adalah egosentris, artinya anak memiliki kesadaran akan diri sendiri sejak tahun pertama usia 
perkembangannya dan akan berkembang sejalan dengan pertambahan pengalamannya. Semakin bertumbuh semakin meningkat pula egoisnya. Sehubungan dengan itu, maka dalam masalah keagamaan anak telah menonjolkan kepentingan dirinya dan telah menuntut konsep-konsep keagamaan yang mereka pandang dari kesenangan pribadinya.

Sifat ketiga dari keagamaan anak usia dini adalah Anthropomorphis, maksudnya anak menggambarkan konsep ketuhanan itu sama dengan konsep manusia, menurut anak Tuhan menghukum orang salah, Tuhan menurut anak yang berusia 6 tahun mempunyai wajah, seperti manusia, punya telinga, mata dan sebagainya, yang jelas Tuhan itu digambarkan sesuai dengan fantasi anak.

Sifat keempat dari keagamaan anak usia dini adalah; verbal dan ritualis.verbal artinya ucapan, maksudnya kehidupan beragama sebahagian besar anak tumbuh dengan cara menghafal kalimat-kalimat keagamaan, selain itu amaliah keagamaan mereka menurut tuntunan pengalaman yang diajarkan kepada mereka (Kamaruddin Hidayat, 2005:1113). Anak yang dibiasakan dari kecil mengucapkan kalimat-kalimat yang baik /bersifat agama dan mengerjakan amaliah-amaliah keagamaan, akan terbawa ketika sudah dewasa dan dihari tua tidak akan terlupakan.

Sifat kelima dari keagamaan anak usia dini adalah imitatif artinya meniru. Maksudnya anak melakukan kegiatan keagamaan berdasarkan apa yang dilihatnya lalu mengerjakannya (meniru) berdoa dan shalat umpamanya, anak melaksanakan karena hasil melihat realitas lingkungan, baik berupa pembiasaan ataupun pengajaran yang intensif. Dalam hal ini anak merupakan peniru yang ulung, sifat peniru ini merupakan modal yang besar dan positif dalam pendidikan ke-agamaan anak.
Sifat keenam atau terakhir dari sifat keagamaan anak adalah rasa heran. maksudnya adalah anak merasa heran dan kagum melihat keindahan sesuatu. Tentu saja kekaguman dan keheranan itu berbeda maknanya dari rasa kagum dan herannya orang dewasa, kekaguman dan keheranan anak hanya bersifat realitas saja akan tetapi kagum dan herannya orang dewasa di samping realitas juga memikirkan ada apa dibalik keindahan realitas tersebut, kekaguman dan keheranan yang ada pada anak belum bersifat kritis dan kreatif.

\section{PENDIDIKAN AGAMA ISLAM PADA ANAK USIA DINI}

Pada uraian tentang perkembangan anak di atas fase pertama dari kehidupan anak adalah fase bayi. Proses pendidikan pada masa ini sudah bersifat langsung. Beberapa aspek kehidupan sudah mampu dilacak dan dimonitor melalui panca indra. Aspek-aspek kehidupan tersebut adalah perkembangan fisik motorik, indra, psikis, sosial, dan agama. Hal ini semua menunjukkan bahwa sibayi pada saat itu, walau belum sempurna organ tubuhnya namum sudah siap menerima pendidikan. Diantara perkembangan indra yang menonjol adalah pendengaran sebagaimana yang diisyarat-kan oleh Allah dalam firman-Nya, dalam surat As-Sajadah ayat 9 .

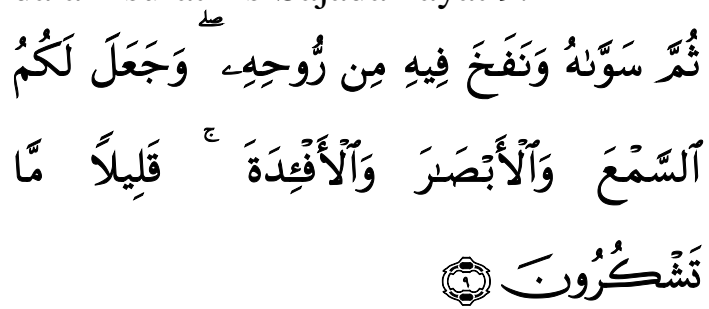

"Dialah yang meniupkan kepadamu roh dan Dialah yang menciptakan kamu dan menjadikan bagi kamu pendengaran, penglihatan dan hati, tetapi amat sedikit kamu yang bersyukur.". 
Ayat tersebut menerangkan bahwa pada saat bayi dilahirkan semua organ tubuhnya belum bekerja dengan sempurna. Maka untuk menuju kearah sempurna fungsinya haruslah melalui latihan dan bimbingan. Dari ayat tersebut juga memberi isyarat kepada kita bahwa pendengaran lebih dahulu berfungsi dari indra lainnya, karena itu harus dimanfaatkan untuk mendengarkan kata-kata dan kalimat yang suci, mengembangkan naluri tauhid yang telah diterimanya jauh sebelum masa kelahiran.

Pada bulan-bulan berikutnya hingga anak berusia dua tahun si bayi sudah mengalami perkembangan yang pesat baik fisik dan psikis. Indranya sudah berfungsi, bayi tadi sudah dapat menangkap isyarat, berjalan, dan sebagainya. Perkembangan yang sedang dialami dapat digunakan untuk menanamkan nilai-nilai agama, seperti perkembangan fungsi bahasa dapat diarahkan kepada pengucpan kata-kata yang baik. Lantunan ayat-ayat suci Al-Qur'an akan sangat mendukung bagi pembentukan pribadi yang baik. Begitu pula sikap dan prilaku orang tua di rumah sangat mempengaruhi prilaku bayi. Secara lahiriyah bayi pasif terhadap agama, namun berkat perkembangan semua indranya bayi aktif mencari, mendapatkan, dan mengenal sesuatu yang baru, itulah semua yang akan mengisi dan mewarnai jati dirinya kelak.

Cara yang efektif dalam menanamkan nilai-nilai keagamaan pada fase ini adalah dengan mendiktekan kalimat tauhid sesuai dengan hadis Nabi, yang artinya adalah: pertama dan tuntunkanlah mereka (mengucapkan) la Ilaha illallah ketika menjelang mati. Pada hadis lain Nabi Muhammad bersabda yang artinya: "Mulailah (mendidik) bayibayi kalian dengan kalimat La Ilaaha Illah".dari Hadis ini diambil isyarat bahwa kalimat tauhid merupakan kalimat yang pertama yang didengar oleh anak, yang diucapkan oleh lidahnya dan merupakan kata-kata dan lafaz yang pertama kali dipahaminya. Kemudian menyuruh mereka shalat jika sudah berusia tujuh tahun sesuai dengan sabda Nabi Saw: "Perintahkanlah anak-anakmu melakukan shalat sejak mereka berumur tujuh tahun, dan pukullah mereka (bila enggan melakukannya) saat mereka berusia sepuluh tahun, dan pisahkanlah tempat tidur mereka,".

Secara rinci, pembinaan agama kepada anak yang sesuai dengan sifat keberagamaan anak maka dapat dilakukan melalui beberapa pendekatan, antara lain:

1. Pembinaan agama lebih banyak bersifat pengalaman langsung seperti salat berjamaah, bersedekah, meramaikan hari raya dengan bersamasama membaca takbir, dan sebagainya. Pengalaman agama secara langsung tersebut ditambah dengan penjelasan sekedarnya saja atau pesanpesan yang disampaikan melalui dongeng, ceritra, main drama, nyanyian, permainan sehingga tidak membebani mental maupun pikiran mereka.

2. Kegiatan agama disesuaikan dengan kesenangan anak-anak, mengingat sifat anak masih egosentris. Sehingga model pembinaan agama bukan mengikuti kemauan orang tua maupun guru saja, melainkan harus banyak variasi agar anak tidak cepat bosan, untuk itu orang tua maupun guru harus banyak ide dan kreativitas tentang srategi dan tekhnik pembinaan keagamaan sehingga setiap anak bisa berganti-ganti pendekatan dan metode walaupun materi yang disampaikan boleh jadi sama.

3. Pengalaman agama anak selain yang didapati dari orang tua, guru dan teman-teman sebaya, mereka juga belajar dari orang-orang yang ada disekitarnya yang tidak mengajarinya secara langsung. Untuk itu pembinaan 
agama anak juga penting dilakukan melalui pembauran secara langsung dengan masyarakat luas yang terkait dengan kegiatan agama seperti pada waktu mengikuti shalat tarwih, shalat hari raya dan sebagainya. Dengan mengajak anak sekali waktu berbaur secara langsung dengan masyarakat yang melakukan peribadatan maka anak akan semakin termotivasi untuk menirukan prilaku-prilaku agama yang di lakukan oleh masyarakat umum, hal ini perlu di lakukan mengingat agama anak masih bersifat anthromorphis.

4. Pembinaan agama kepada anak juga perlu dilakukan secara berulang-ulang melalui ucapan yang jelas serta tindakan secara lansung. Seperti mengajari anak shalat, maka lebih dahulu di ajarkan tentang hafalan bacaan shalat secara berulang-ulang hingga hafal bacaan shalat di luar kepala sekaligus diiringi dengan tindakan shalat secara lansung dan akan lebih menarik apabila dilakukan bersama teman-teman nya, demikian juga kepada materi-materi pembinaan agama lainnya.

5. Mengingat agama masih imitatif, pemberian contoh nyata dari orang tua guru dan masyarakat lingkungannya sangat penting, untuk itu dalam proses pembinaan tersebut

\section{DAFTAR RUJUKAN}

Anwar, 2003. Pendidikan Anak Dini Usia, (Panduan Praktis Bagi Ibu dan Calon Ibu), Bandung, Alfabeta

Mansur, 2007. Pendidikan Anak Usia Dini dalam Islam, Yogyakarta, Pustaka pelajar

Abdullah Nasih Ulwan, 1990. Pendidikan Anak Menurut Islam: Pemeliharaan Kesehatan Jiwa Anak, Bandung, Remaja Rosdakarya prilaku orang tua harus benar-benar dapat di contoh anak, baik secara ucapan maupun tindakan.

6. Melakukan kunjungan ke tempattempat yang bersejarah seperti masjid-masjid besar pondok-pondok pesantren dan peninggalan sejarah Islam.

\section{PENUTUP}

Pendidikan agama Islam yang diberikan oleh orang tua dan guru kepada anak usia dini sangat penting, karena pada masa ini anak sedang mengalami masa tahap awal pertumbuhan dan perkembangannya dan sangat tepat sekali pada masa ini pendidikan agama Islam diberikan antara lain dengan cara memberikan contoh teladan, berceritra, berdongeng, membawa anak ke alam nyata, untuk melihat keangungan dan kebesaran Tuhan, melatih anak-anak untuk membiasakan anak beribadah, berakhlak mulia, belajar sosial serta orang tua hendaklah mampu untuk menciptakan suasana yang kondusif dan menyenangkan, sehingga menimbulkan semangat dan motivasi bagi anak-anak mengenal Tuhannya, diharapkan pendidikan agama Islam ini menjadi pondasi untuk kehidupan anak kelak dikemudian hari setelah dewasa..

UU RI Nomor 20 tahun 2003 tentang Sistem Pendidikan Nasional.

Muhammad Zuhaili, 2002. Pentingnya Pendidikan Islam Sejak Dini, Jakarta, A.H.Ba'adillah Press

Baharuddin dan Mulyono, 2008. Psikologi Agama dalam Perspektif Islam, Malang, UIN-Press, 


\section{Indeks}

, keberagamaan, 1

anak, 1, 186, 187, 188, 189, 190, 191

perkembangan, 1, 186, 187, 188, 190 pertumbuhan, 1, 186, 191

usia dini, 1, 186, 187, 188, 189, 191

* Penulis adalah Lektor Kepala dalam Mata Kuliah Evaluasi Pendidikan STAIN Batusangkar 